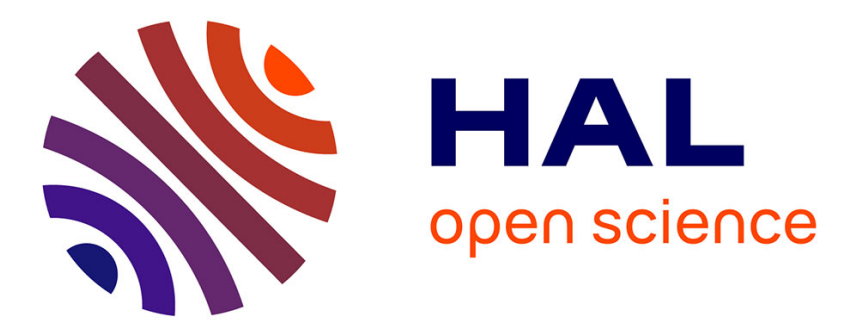

\title{
Infrared Spectroscopy and Density Functional Theory Investigations of the Reactivity of Titanium Atoms with Carbon Monoxide and Water Isolated in Solid Argon: Sequential Evolution from Triplet to Singlet State
}

M Ibrahim, P Soulard, M E Alikhani, B Tremblay

\section{- To cite this version:}

M Ibrahim, P Soulard, M E Alikhani, B Tremblay. Infrared Spectroscopy and Density Functional Theory Investigations of the Reactivity of Titanium Atoms with Carbon Monoxide and Water Isolated in Solid Argon: Sequential Evolution from Triplet to Singlet State. Journal of Physical Chemistry A, 2020, 10.1021/acs.jpca.9b10909 . hal-03001005

\section{HAL Id: hal-03001005 \\ https://hal.science/hal-03001005}

Submitted on 12 Nov 2020

HAL is a multi-disciplinary open access archive for the deposit and dissemination of scientific research documents, whether they are published or not. The documents may come from teaching and research institutions in France or abroad, or from public or private research centers.
L'archive ouverte pluridisciplinaire HAL, est destinée au dépôt et à la diffusion de documents scientifiques de niveau recherche, publiés ou non, émanant des établissements d'enseignement et de recherche français ou étrangers, des laboratoires publics ou privés. 


\title{
Infrared Spectroscopy and Density Functional Theory Investigations of the Reactivity of Titanium Atoms with Carbon Monoxide and Water Isolated in Solid Argon: Sequential Evolution from Triplet to Singlet State
}

\author{
M. Ibrahim, P. Soulard, M. E. Alikhani*, and B. Tremblay*
}

Sorbonne Université, CNRS, UMR 8233, MONARIS, Case courrier 49, 4 place Jussieu, F-75005, Paris, France

\begin{abstract}
Thermally evaporated titanium atoms react with carbon monoxide and water in solid argon at $12 \mathrm{~K}$ to produce the $\mathrm{HTiOH}-\mathrm{CO}$ and $\mathrm{HTiOH}-(\mathrm{CO})_{2}$ molecules which are were characterized using infrared spectroscopy on the basis of $\mathrm{CO}, \mathrm{Ti}$, and water concentration variations and of isotopic substitutions. The insertion product, $\mathrm{HTiOH}$, resulting from the reaction of a titanium atom with a water molecule reacts with $\mathrm{CO}$ spontaneously to give the $\mathrm{HTiOH}-\mathrm{CO}$ molecule which in turn reacts with a second $\mathrm{CO}$ molecule to give HTiOH-(CO) $)_{2}$ The Density Functional Theory (DFT) calculations have been carried out to elucidate the geometrical and electronic structures and support the spectral assignments. The topological analysis of the charge density within the experimentally observed molecules allowed us to rationalize the coordination sphere as well as the electron pairing on the titanium center.
\end{abstract}

\footnotetext{
*Authors to whom correspondence should be addressed.

E-mail:esmail.alikhani@sorbonne-universite.fr, Tel :33144273072; benoit.tremblay@sorbonne-universite.fr,
} Tel : 33144273835 


\section{INTRODUCTION}

The water gas shift reaction, $\mathrm{CO}+\mathrm{H}_{2} \mathrm{O} \rightarrow \mathrm{CO}_{2}+\mathrm{H}_{2}$ is frequently applied in the chemical process industry for $\mathrm{H}_{2}$ production $^{1}$ and it also plays a secondary role in many proposed future technologies for energy conversion. Many experimental ${ }^{2-4}$ and theoretical ${ }^{5}$ studies have been performed to elucidate the reaction mechanisms and investigate the catalytic active species.

Reactions of laser-ablated transition metals with two ligands have been investigated in solid argon or neon. Andrews has studied the reactions of ruthenium atoms with $\mathrm{CO}+\mathrm{H}_{2}$ mixtures in which $\mathrm{H}_{2} \mathrm{Ru}(\mathrm{CO})_{\mathrm{x}}$ $(x=1-4)$ molecules were formed and identified in solid argon ${ }^{6}$. A second investigation, carried out on the interaction of $\mathrm{Mn}, \mathrm{Fe}, \mathrm{Co}$ and $\mathrm{Ni}$ atoms with $\mathrm{O}_{2}+\mathrm{H}_{2}$ mixtures, $\mathrm{M}(\mathrm{OH})_{1,2,3}$ molecules were characterized in solid $\operatorname{argon}^{7}$. In a study where metal atoms were reacted with $\mathrm{N}_{2}+\mathrm{CO}, \mathrm{Xu}$ and co-workers identified NNMCO $(\mathrm{M}=\mathrm{Ta}, \mathrm{Nb}),(\mathrm{NN})_{2} \mathrm{TaCO}$ and $\mathrm{NNTa}(\mathrm{CO})_{2}$ molecules in solid neon ${ }^{8}$, while copper atoms with $\mathrm{CO}+\mathrm{N}_{2}$ mixture in solid argon resulted in the formation of the $\mathrm{NNCuCO}$ and $(\mathrm{NN})_{2} \mathrm{CuCO}$ complexes ${ }^{9}$. The latter results show that the preadsorption of $\mathrm{CO}$ on $\mathrm{Cu}$ atoms promotes adsorption of $\mathrm{N}_{2}$. Additionally $\mathrm{Xu}$ has studied the interaction of $\mathrm{Cu}, \mathrm{Ag}$ and $\mathrm{Au}$ atoms with $\mathrm{O}_{2}$ and $\mathrm{CO}$ and different molecules have been characterized : $\left(\mathrm{O}_{2}\right) \mathrm{Cu}(\mathrm{CO})_{1,2}, \mathrm{OO}(\mathrm{M}) \mathrm{CO}(\mathrm{M}=\mathrm{Cu}, \mathrm{Ag}), \mathrm{OCAuO}_{2} \mathrm{CO}$ and $\mathrm{OAuCO}^{10}$. Finally, Zhou has studied the interactions of water molecules with platinum dioxygen complex and dioxide molecule and three $\mathrm{PtO}_{2}-\mathrm{H}_{2} \mathrm{O}$ complexes were identified ${ }^{11}$. In another work, the reactions of early lanthanide metal atoms $(\mathrm{Ce}$, Pr, and Nd) with carbon monoxide and nitric oxide have been investigated. The results show that the reactions proceed with the initial formation of a linear inserted NLnO molecules which subsequently reacts with $\mathrm{CO}$ to form the $\mathrm{NLnO}(\mathrm{CO})$ complexe ${ }^{12}$.

Experimental and theoretical investigations have been carried out on the reactions of titanium atoms with water exclusively. Using infrared spectroscopy, Kauffman et al. showed that thermally evaporated Sc, $\mathrm{Ti}$ and $\mathrm{V}$ atoms in solid argon could react spontaneously with water molecules to form the insertion product $\mathrm{HMOH}^{13}$. They have observed, without knowing it, the Ti-O stretching mode of the $\mathrm{H}_{2} \mathrm{TiO}$ molecule, which they mistakenly assigned to the $\mathrm{TiO}$ molecule. Zhou and co-workers have studied the reactivity of laser evaporated $\mathrm{Ti}, \mathrm{V}, \mathrm{Nb}, \mathrm{Zr}$ and $\mathrm{Hf}$ atoms with water in solid argon by infrared spectroscopy and with the help 
of theoretical frequency calculations ${ }^{14,15}$. Their findings show that the metals react spontaneously with water molecules to form insertion product $\mathrm{HMOH}$ and $\mathrm{H}_{2} \mathrm{M}(\mathrm{OH})_{2}$. In the case of the Ti atoms, the photolysis induces two reactional pathways for $\mathrm{HTiOH}$ : rearrangement to form $\mathrm{H}_{2} \mathrm{TiO}$ isomer and $\mathrm{H}_{2}$ elimination to form the monoxide, TiO.

The reactivity of titanium clusters with $\mathrm{CO}$ has received attention in the last decade. On one hand, when laser-ablated titanium atoms are codeposited with carbon monoxide, $\operatorname{Ti}(\mathrm{CO})_{\mathrm{n}}(\mathrm{n}=1-6)^{16}, \mathrm{Ti}_{2}(\mathrm{CO})_{\mathrm{n}}$ $(n=1,2)$, and $\mathrm{Ti}_{3}(\mathrm{CO})_{\mathrm{n}}(\mathrm{n}=1-3)$ molecules have been characterized in solid $\operatorname{argon}^{16,17}$ or neon ${ }^{18}$. On the other hand, when thermally evaporated $\mathrm{Ti}$ atoms react with $\mathrm{CO}$, the $\mathrm{TiCO}$ molecule is not observed, but $\mathrm{Ti}_{2} \mathrm{CO}$ and $\mathrm{OTi}_{2} \mathrm{C}$ are observed in solid argon and neon ${ }^{19}$.

In this paper, we present the study of the reactivity of thermally evaporated titanium atoms with carbon monoxide and water in solid argon at $12 \mathrm{~K}$. Infrared spectroscopy coupled with density functional calculations provide-evidences for the formation of two molecules $\mathrm{HTiOH}-\mathrm{CO}$ and $\mathrm{HTiOH}-(\mathrm{CO})_{2}$.

\section{Experimental and Computational Details}

The experimental setup for matrix isolation Fourier transform infrared (FTIR) spectroscopic investigation has been described in detail previously ${ }^{20}$. Briefly, the samples were prepared by co-condensing Ti vapors and $\mathrm{CO}$ ( 1 to $4 \% \mathrm{CO}$ in $\mathrm{Ar}$ ) and $\mathrm{H}_{2} \mathrm{O}(0.5 \%$ to $1 \%)$ mixtures in argon onto one of six flat, highly polished, Rh-plated copper mirrors maintained at $12 \mathrm{~K}$ using a closed cycle cryogenerator (model PT405, Cryomech, Syracuse, NY, USA) situated in a stainless-steel cell evacuated at a base pressure less than $5 \times 10^{-7}$ mbar. A Ti-Mo filament (Goodfellow, $85 \% \mathrm{Ti}$ ) was heated at about $1500^{\circ} \mathrm{C}$ to generate $\mathrm{Ti}$ vapor. The metal's deposition rate was carefully monitored with the aid of a quartz microbalance and was typically of the order of 1-10 $\mu \mathrm{g} \mathrm{min}^{-1}$. High-purity argon (Prodair; 99.995\%), carbon monoxide (Matheson; 99.5\%), ${ }^{13} \mathrm{C}^{16} \mathrm{O}$ (CEA, Saclay, France, 99\% ${ }^{13} \mathrm{C}^{16} \mathrm{O}$ including $\left.9 \%{ }^{13} \mathrm{C}^{18} \mathrm{O}\right),{ }^{12} \mathrm{C}^{18} \mathrm{O}\left(\mathrm{MSD} ; 98 \%{ }^{18} \mathrm{O}\right.$ ) and $\mathrm{H}_{2}{ }^{16} \mathrm{O}, \mathrm{H}_{2}{ }^{18} \mathrm{O}$ $\left(98 \%{ }^{18} \mathrm{O}\right)$ and $\mathrm{D}_{2}{ }^{18} \mathrm{O}\left(98.4 \%{ }^{18} \mathrm{O}\right)$ were used to prepare the $\mathrm{CO}-\mathrm{Ar}$ and $\mathrm{H}_{2} \mathrm{O}-\mathrm{Ar}$ mixtures after removing condensable impurities with a liquid- $\mathrm{N}_{2}$ trap.

In general, after 15-90 min of deposition, infrared spectra of the resulting sample were recorded at 0.1 $\mathrm{cm}^{-1}$ resolution in the transmission-reflection mode between 4000 and $70 \mathrm{~cm}^{-1}$ using a Bruker 120 FTIR 
spectrometer and suitable combinations of $\mathrm{KBr} / \mathrm{Ge}$ or $\mathrm{Si} / \mathrm{Mylar}(6 \mu \mathrm{m})$ beamsplitters with either liquid- $\mathrm{N}_{2^{-}}$ cooled InSb or narrow-band $\mathrm{HgCdTe}$ photodiodes or a liquid-He-cooled Si-B bolometer, fitted with cooled bandpass filters. Bare mirror backgrounds were used as references in processing the sample spectra. Also, absorption spectra in the mid- and far infrared were collected on the same samples through either CsI or polyethylene windows mounted on a rotatable flange separating the interferometer vacuum $\left(10^{-3} \mathrm{mbar}\right)$ from the cryostatic cell $\left(10^{-7} \mathrm{mbar}\right)$. The spectra were subsequently subjected to baseline correction to compensate for infrared light scattering and interference patterns. The sample can be annealed in order to increase the abundance of aggregates.

Molecular geometries were optimized using the DFT B3LYP method with a correlation consistent basis set of triple-zeta quality (cc-pVTZ) for C, O and Ti atoms and the cc-pVTZ-PP basis set with extended relativistic pseudo-potentials for Ti obtained from the Basis Set Exchange (BSE) software and the EMSL Basis Set Library. ${ }^{21-22}$ All calculations have been performed with the Gaussian 09 quantum chemical package $^{23}$. Vibrational frequency analysis has been done within the harmonic approximation. The nature of chemical bonds between metal-ligand has been investigated using the QTAIM topological approach ${ }^{24}$ with the AIMALL software ${ }^{25}$.

\section{EXPERIMENTAL RESULTS}

Two samples were first prepared with Ti vapor: a first one with a $\mathrm{CO} / \mathrm{Ar}$ concentration of $0.5 \%$ and a second with a $\mathrm{H}_{2} \mathrm{O} / \mathrm{Ar}$ concentration of $1 \%$ (spectra (a) and (b) in Figure 1). Some absorptions of products of Ti species with CO molecule were observed at 707.0, 754.4, and $769.8 \mathrm{~cm}^{-1}$ and assigned to $\mathrm{OTi}_{2} \mathrm{C}^{19}$, while two absorptions in the $\mathrm{CO}$ stretching region at 1866.7 and $1862.8 \mathrm{~cm}^{-1}$ were assigned by Andrews ${ }^{16}$ to OTiCO and $\mathrm{OTi}(\mathrm{CO})_{2}$ (Figure 1a). Other absorptions assigned by $\mathrm{Zhou}^{14}$ and Margrave ${ }^{13}$ to Ti species with water are dominant in the Ti-H and Ti-O stretching regions: peaks at 1538,1549 , and $699.6 \mathrm{~cm}^{-1}$ assigned to $\mathrm{HTiOH}$, at 1646.7 and $1010.8 \mathrm{~cm}^{-1}$ assigned to $\mathrm{H}_{2} \mathrm{TiO}^{14}$, and at 1666.0 and $1689.8 \mathrm{~cm}^{-1}$ assigned to $\mathrm{H}_{2} \mathrm{Ti}(\mathrm{OH})_{2}{ }^{14}$ (Figure 1b). For a sample with $\mathrm{Ti}$ atoms and a $\mathrm{CO}+\mathrm{H}_{2} \mathrm{O}$ mixture, new bands were observed in O-H, C-O, Ti-H and Ti-O stretching regions at 3745.6, 2039.9, 1931.7, 1926.3, 1911.4, 1908.1 1577.4, 1549.4, 1543.8, 713.0, and $702.6 \mathrm{~cm}^{-1}$ (Table 1). Other weak bands were observed, but no definitive 
identification is possible. The band at $1595.5 \mathrm{~cm}^{-1}$ appears without the Ti vapor and has been previously assigned to the $(\mathrm{CO})_{2}-\mathrm{H}_{2} \mathrm{O}$ complex ${ }^{26}$. The new absorptions are indicated by arrows (except the bands at 3745.6 and $2039.9 \mathrm{~cm}^{-1}$ ) in Figure 1. In order to attribute these bands to a specific species, experiments were done by performing several concentration studies and isotopic substitutions.

A series of experiments were performed using different $\mathrm{Ti}$ concentrations. When we increase the titanium flow rate by a factor of 2 , with a constant $\mathrm{CO} / \mathrm{H}_{2} \mathrm{O} / \mathrm{Ar}$ concentration of $20 / 10 / 1000$, we observed that the intensities of the new bands in Figure 1 are multiplied by 2 . We note the same intensity variation for both bands at 1866.7 and $1862.8 \mathrm{~cm}^{-1}$ which correspond to the species OTiCO and OTi(CO) ${ }_{2}{ }^{16}$ and this suggests that all the new bands correspond to species that contain one titanium atom (Figure 1 and 2).

Table 1. Experimental vibrational frequencies and isotopic shifts (in $\mathrm{cm}^{-1}$ ) for the observed molecules.

\begin{tabular}{cccccccccc}
\hline \multicolumn{7}{c}{$\mathrm{H}_{2} \mathrm{O}+\mathrm{CO}$ isotopes } & \multicolumn{7}{c}{$\mathrm{CO}+\mathrm{H}_{2} \mathrm{O}$ isotopes } \\
\hline${ }^{12} \mathrm{C}^{16} \mathrm{O}$ & ${ }^{13} \mathrm{C}^{16} \mathrm{O}$ & $\Delta v$ & ${ }^{12} \mathrm{C}^{18} \mathrm{O}$ & $\Delta v$ & $\mathrm{H}_{2}{ }^{18} \mathrm{O}$ & $\Delta v$ & $\mathrm{D}_{2}{ }^{18} \mathrm{O}$ & $\Delta v$ & Modes \\
\hline 3745.5 & 3745.4 & 0.1 & 3745.5 & 0 & 3733.5 & 12.0 & - & & $v_{\mathrm{OH}}$ \\
$2039.9^{\mathrm{a}}$ & 1994.0 & 45.9 & 1993.5 & 46.4 & 2039.8 & 0.1 & 2038.9 & 1.0 & $v_{\mathrm{CO}}$ \\
1931.7 & 1889.0 & 42.7 & 1887.5 & 44.2 & 1931.5 & 0.2 & 1929.1 & 2.6 & $v_{\mathrm{CO}}$ \\
1926.3 & 1883.7 & 42.6 & 1882.3 & 44.0 & 1926.1 & 0.2 & 1923.5 & 2.8 & $v_{\mathrm{CO}}$ \\
$1911.4{ }^{\mathrm{b}}$ & 1869.6 & 41.8 & 1865.3 & 46.1 & 1911.4 & 0.0 & 1910.9 & 0.5 & $v_{\mathrm{CO}}$ \\
1908.1 & 1866.5 & 41.6 & 1862.2 & 45.9 & 1908.4 & 0.0 & 1907.8 & 0.3 & $v_{\mathrm{CO}}$ \\
1577.4 & 1577.3 & 0.1 & 1577.3 & 0.1 & 1577.4 & 0.0 & 1138.4 & 439.0 & $v_{\text {Ti-H }}$ \\
1549.4 & 1549.1 & 0.3 & 1549.0 & 0.4 & 1549.3 & 0.1 & 1120.4 & 429.0 & $v_{\text {Ti-H }}$ \\
1543.8 & 1543.4 & 0.4 & 1543.3 & 0.5 & 1543.6 & 0.2 & 1116.9 & 426.9 & $v_{\text {Ti-H }}$ \\
713.0 & - & - & - & - & - & - & - & - & $v_{\text {Ti-OH }}$ \\
702.6 & - & - & 702.0 & 0.6 & 674.9 & 27.7 & 656.3 & 46.3 & $v_{\text {Ti-OH }}$ \\
389.2 & 386.0 & 3.2 & 385.6 & 3.6 & 387.3 & 1.9 & 352.7 & 36.5 & n.a. ${ }^{\mathrm{c}}$ \\
358.7 & 353.3 & 5.4 & 356.8 & 1.9 & 358.1 & 0.6 & - & - & n.a. \\
312.2 & - & - & - & - & 312.2 & 0.0 & 281.5 & 30.7 & n.a. \\
\hline
\end{tabular}

${ }^{a}$ With the ${ }^{12} \mathrm{C}^{16}+{ }^{12} \mathrm{C}^{18} \mathrm{O}$ mixture, a new band appears at $2020.7 \mathrm{~cm}^{-1}$ 
${ }^{\mathrm{b}}$ With the ${ }^{12} \mathrm{C}^{16}+{ }^{12} \mathrm{C}^{18} \mathrm{O}$ mixture, a new band appears at $1884.2 \mathrm{~cm}^{-1}$

${ }^{\mathrm{c}}$ n.a.: not attributed bands
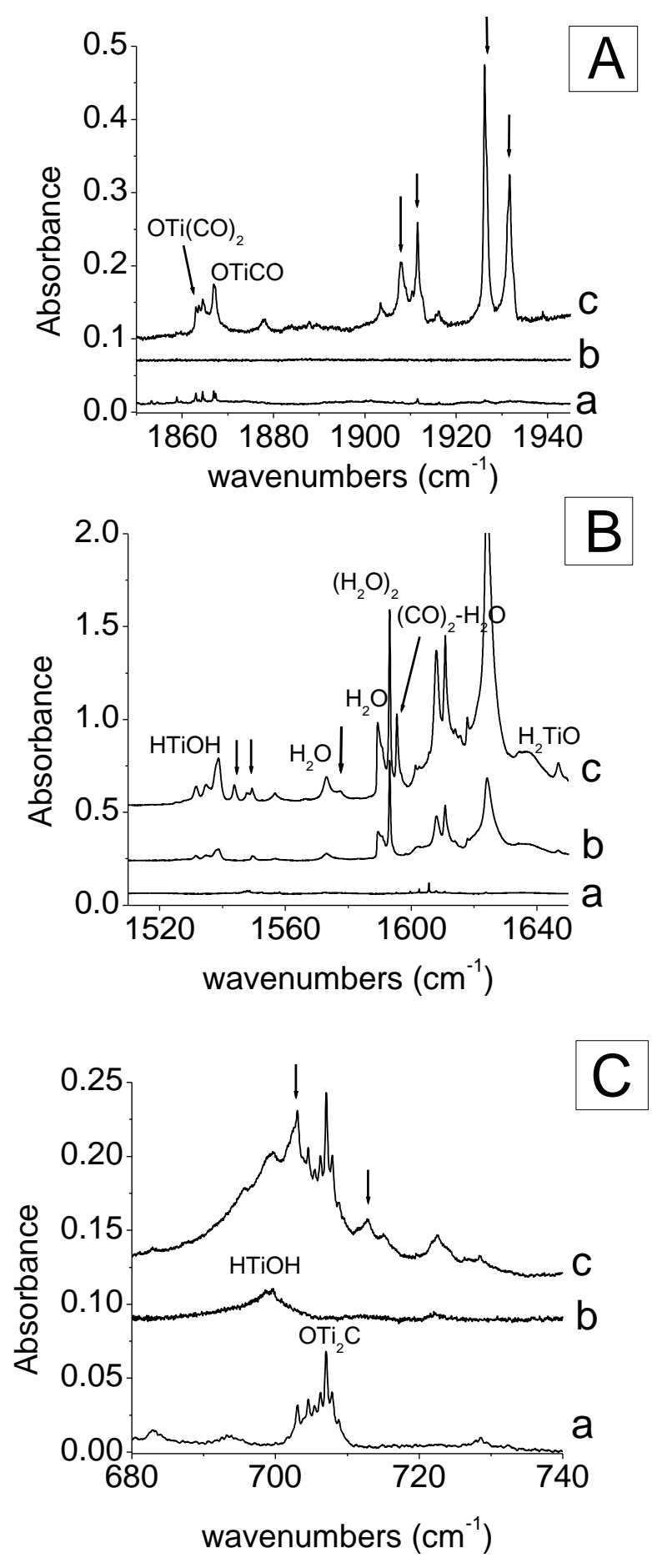

Figure 1. Infrared spectra in the (A) $\mathrm{C}-\mathrm{O},(\mathrm{B}) \mathrm{Ti}-\mathrm{H}$ and (C) Ti-OH stretching regions of the Ti+CO+H${ }_{2} \mathrm{O}$ reaction products at $12 \mathrm{~K}$. Ti/CO/H $\mathrm{H}_{2} \mathrm{O} / \mathrm{Ar}=$ (a) 0.2/20/0/1000, (b) 0.2/0/10/1000, and (c) 0.2/20/10/1000. 

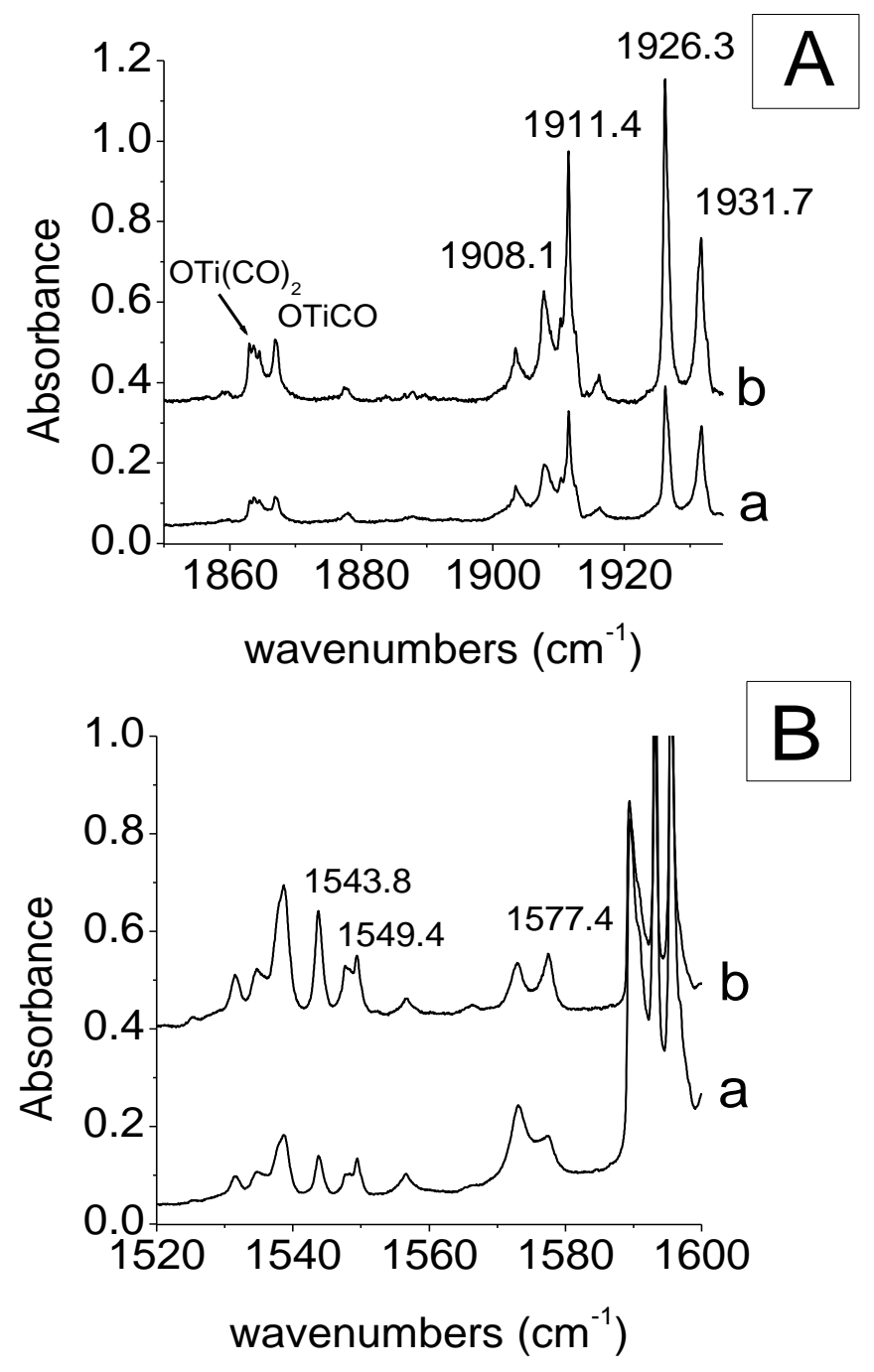

Figure 2. Infrared spectra in the (A) $\mathrm{C}-\mathrm{O}$ and (B) $\mathrm{Ti}-\mathrm{H}$ stretching regions of the $\mathrm{Ti}+\mathrm{CO}+\mathrm{H}_{2} \mathrm{O}$ reaction products at $12 \mathrm{~K}$. Ti/CO/H $\mathrm{H}_{2} \mathrm{O} / \mathrm{Ar}=($ a) $0.3 / 20 / 10 / 1000$ and (b) 0.6/20/10/1000.

Experiments were done with CO concentrations of $1 \%$ and $2 \%$ and with a constant water (1\%) and metal $(600 \mathrm{ppm})$ concentration. The infrared spectra in the $\mathrm{C}-\mathrm{O}$ and $\mathrm{Ti}-\mathrm{H}$ regions are presented in Figure 3. The comparison between these two spectra shows that the intensities of the bands at 1931.7, 1926.3, 1866.8 (OTiCO), 1543.8, and $1549.4 \mathrm{~cm}^{-1}$ increase by a factor of 2 , but the bands at 1911.4, 1908.1, 1862.4 $\left(\mathrm{OTi}(\mathrm{CO})_{2}\right)$, and $1577.4 \mathrm{~cm}^{-1}$ increase by a factor of 4 . This suggests that the first group of bands corresponds to a species containing one $\mathrm{CO}$ molecule and the others to a species containing more than one CO (Table 1). Note that the bands observed at 713.0 and $702.6 \mathrm{~cm}^{-1}$ in the Ti-O region correlate with those containing one CO. To correlate the band in the O-H stretching region at $3745.6 \mathrm{~cm}^{-1}$ with the others, two samples were prepared at a lower water concentration $(0.5 \%)$ but with two different CO concentrations, $2 \%$ 
and $4 \%$ and with a constant Ti concentration of about $450 \mathrm{ppm}$. The band at $3745.6 \mathrm{~cm}^{-1}$ becomes more intense at higher concentration, which correlates with our observation for the band at $1577.4 \mathrm{~cm}^{-1}$ which has the same behavior (Figure S1 in the Supporting Information).
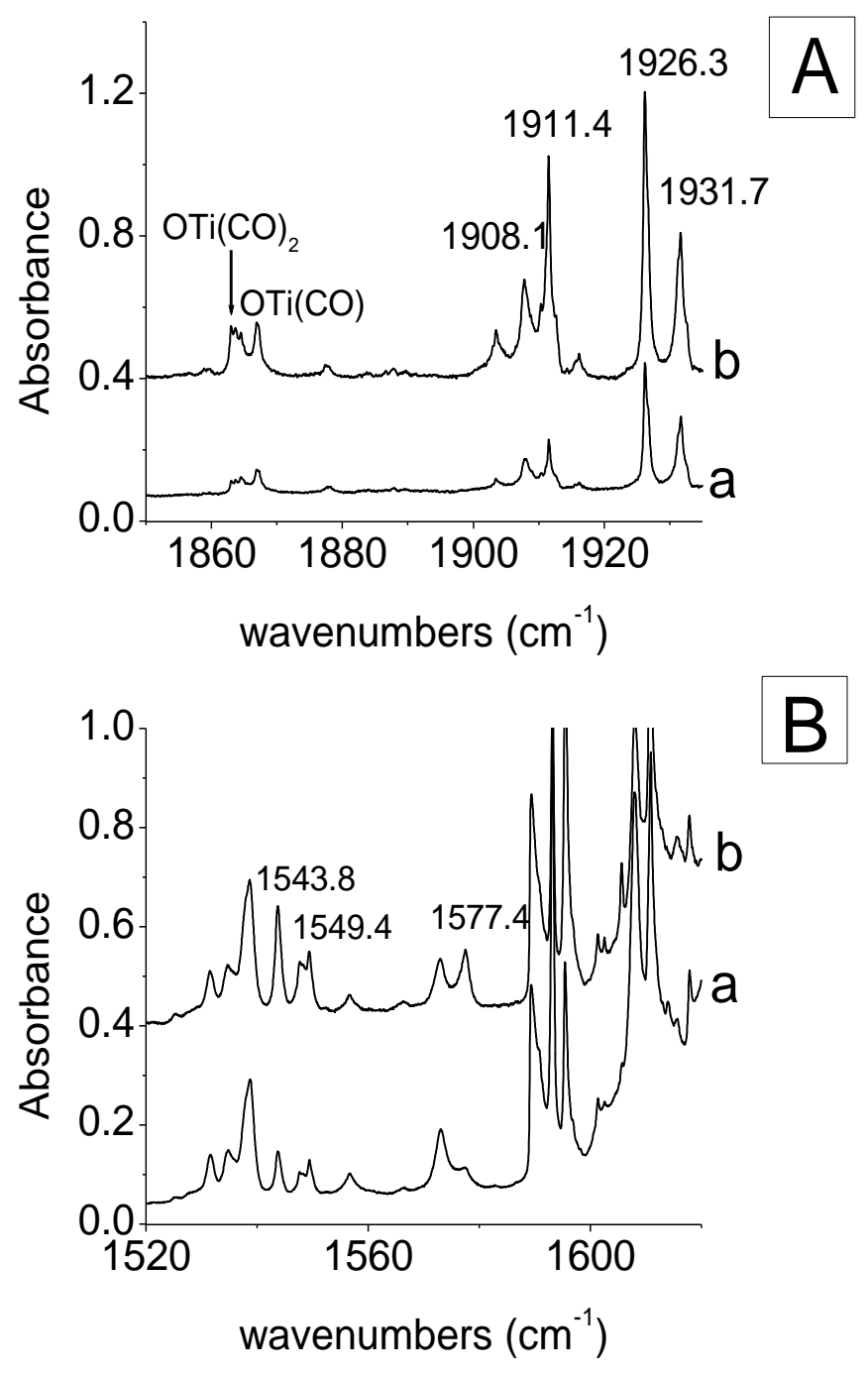

Figure 3. Infrared spectra in the (A) $\mathrm{C}-\mathrm{O}$ and (B) $\mathrm{Ti}-\mathrm{H}$ stretching regions of the $\mathrm{Ti}+\mathrm{CO}+\mathrm{H}_{2} \mathrm{O}$ reaction products at $12 \mathrm{~K}$. Ti/CO/H $\mathrm{H}_{2} \mathrm{O} / \mathrm{Ar}=(a) 0.6 / 10 / 10 / 1000$ and $(b) 0.6 / 20 / 10 / 1000$.

Complementary experiments were performed with $0.5 \%$ and $1 \%$ water concentrations with a constant $\mathrm{CO}$ and $\mathrm{Ti}$ concentration (1\% and $450 \mathrm{ppm}$, respectively). In the $\mathrm{C}-\mathrm{O}$ and $\mathrm{Ti}-\mathrm{H}$ stretching regions (Figure 4), when we increase the water concentration by a factor of 2, the intensities of the bands noted in Figure 4 increase by a factor of 2 . This suggests that the molecules corresponding to these bands contain one water molecule. We can conclude that the absorptions at 1926.3, 1931.7, 1543.7, 1549.4, 713.0 and $702.6 \mathrm{~cm}^{-1} \mathrm{can}$ 
be correlated together and attributed to the same species containing one $\mathrm{CO}$ and one $\mathrm{H}_{2} \mathrm{O}$ molecule, and the other absorptions at $3745.6,2039.9,1911.4,1908.1$, and $1577.4 \mathrm{~cm}^{-1}$ have the same behavior and belong to another species containing two $\mathrm{CO}$ molecules and one $\mathrm{H}_{2} \mathrm{O}$ molecule.

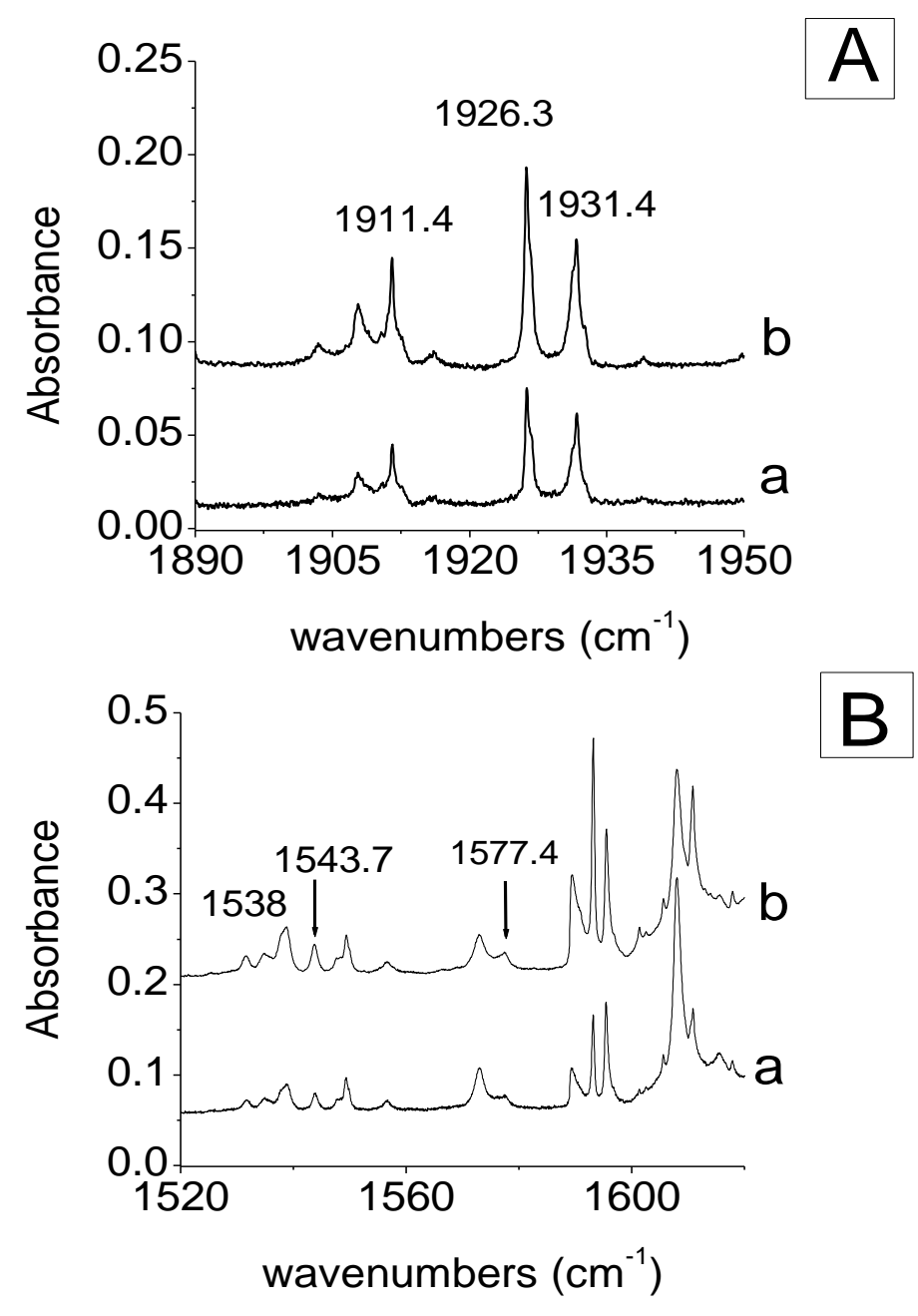

Figure 4. Infrared spectra in the (A) $\mathrm{C}-\mathrm{O}$ and (B) $\mathrm{Ti}-\mathrm{H}$ stretching regions of the $\mathrm{Ti}+\mathrm{CO}+\mathrm{H}_{2} \mathrm{O}$ reaction products at $12 \mathrm{~K} . \mathrm{Ti} / \mathrm{CO} / \mathrm{H}_{2} \mathrm{O} / \mathrm{Ar}=(a) 0.45 / 10 / 5 / 1000$ and $(b) 0.45 / 10 / 10 / 1000$.

The bands for the species with one CO molecule present two different trapping sites (Table 1) and it was possible to discriminate them by annealing. After an annealing to $32 \mathrm{~K}$, the intensities of the bands at $1926.3,1543.8$ and $702.6 \mathrm{~cm}^{-1}$ remain almost unchanged but the intensities of the ones at $1931.7,1549.4$ and $713.0 \mathrm{~cm}^{-1}$ increase by almost a factor of three (Figure S2). We can easily conclude that each doublet (Table 1) for each mode corresponds to two different trapping sites of the same species. The species with two CO 
molecules has also two different trapping sites at 1911.4 and $1908.1 \mathrm{~cm}^{-1}$, but in this case the first band is always the most intense, independently of the experimental conditions and the annealing temperature.

Accompanying these absorptions in the $\mathrm{O}-\mathrm{H}, \mathrm{C}-\mathrm{O}, \mathrm{Ti}-\mathrm{H}$, and $\mathrm{Ti}-\mathrm{OH}$ stretching regions much weaker absorptions in the far infrared region have been observed. In order to correlate these bands with those observed in the mid-infrared region, several samples were prepared using different $\mathrm{CO}$ and $\mathrm{H}_{2} \mathrm{O}$ concentrations. Figure 5a represents a spectrum with only a deposition of $\mathrm{Ti}$ and $\mathrm{H}_{2} \mathrm{O}$ in Ar. For a sample with a $\mathrm{CO} / \mathrm{H}_{2} \mathrm{O} / \mathrm{Ar}$ molar ratio of 10/10/1000, we observed four new absorptions at 389.2, 358.7, 330.4, and $312.2 \mathrm{~cm}^{-1}$ (Figure $5 \mathbf{b}$ ). The other absorptions belong to species containing only $\mathrm{Ti}$ and water and are correlated with those observed in the $\mathrm{Ti}-\mathrm{H}$ and $\mathrm{Ti}-\mathrm{O}$ stretching regions. When we increase the $\mathrm{CO}$ concentration to $2 \%$, these bands become more intense (Figure 5c), and with a higher CO concentration of 4\% (Figure 5d), we observed that the intensity of the band at $330.4 \mathrm{~cm}^{-1}$ decreases by about $30 \%$. We observe the same decrease for the species containing one CO molecule (Table 2). For the bands observed at $389.2,358.7$, and $312.2 \mathrm{~cm}^{-1}$, the precise measurement of the intensities is impossible and they cannot be correlated with other observed bands.

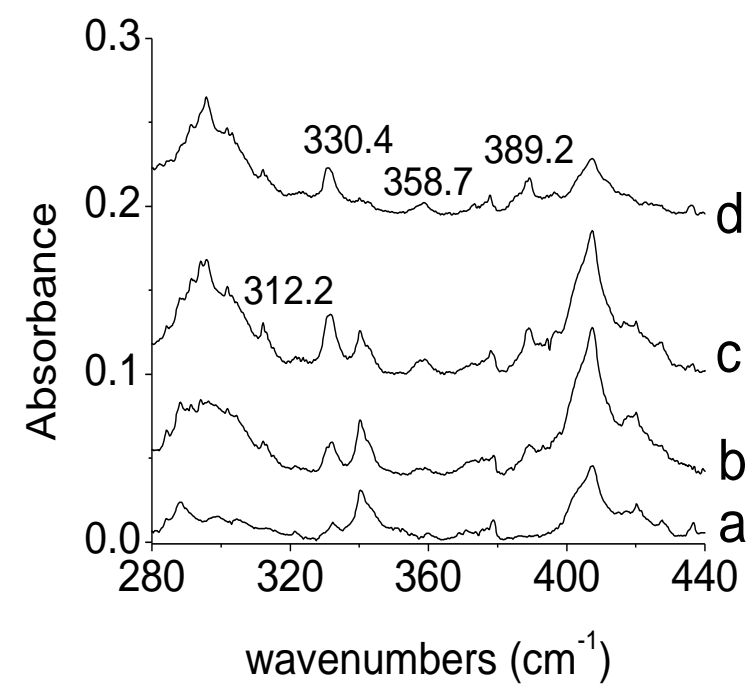

Figure 5. Infrared spectra in the Far-infrared region of the (a) $\mathrm{Ti}+\mathrm{H}_{2} \mathrm{O}$ and (b), (c), (d) $\mathrm{Ti}+\mathrm{CO}+\mathrm{H}_{2} \mathrm{O}$ reaction products at $12 \mathrm{~K}$. Ti/Ar=0.45/1000 with $\mathrm{CO} / \mathrm{H}_{2} \mathrm{O} / \mathrm{Ar}$ molar ratios of (a) 0/10/1000, (b) 10/10/1000, (c) 20/10/1000, and (d) 40/5/1000. 
Isotopic substitutions were carried out using ${ }^{13} \mathrm{C}^{16} \mathrm{O},{ }^{12} \mathrm{C}^{18} \mathrm{O}, \mathrm{CO}+{ }^{12} \mathrm{C}^{18} \mathrm{O}$ mixture, $\mathrm{H}_{2}{ }^{18} \mathrm{O}$, and $\mathrm{D}_{2}{ }^{18} \mathrm{O}$. The results are presented in Figure 6 for the $\mathrm{C}-\mathrm{O}$ stretching region and in Figure $\mathbf{S 3}$ for the Ti-OH stretching region and they are reported in Table 1. With the CO isotopes, the 1931.7 and $1926.3 \mathrm{~cm}^{-1}$ absorptions shift to 1889.0 and $1883.7 \mathrm{~cm}^{-1}$ with ${ }^{13} \mathrm{C}^{16} \mathrm{O}$, and to 1887.5 and $1882.3 \mathrm{~cm}^{-1}$ with ${ }^{12} \mathrm{C}^{18} \mathrm{O}$ (Figure 6). With the ${ }^{12} \mathrm{C}^{16} \mathrm{O}+{ }^{12} \mathrm{C}^{18} \mathrm{O}$ mixture, the spectrum only provides the sum of each isotopic band, implying that one CO unit is involved in this mode. The bands at 2039.9 and $1911.4 \mathrm{~cm}^{-1}$ shift to 1994.0 and 1869.6 $\mathrm{cm}^{-1}$ with ${ }^{13} \mathrm{C}^{16} \mathrm{O}$, and to 1993.5 and $1865.3 \mathrm{~cm}^{-1}$ with ${ }^{12} \mathrm{C}^{18} \mathrm{O}$. With a ${ }^{12} \mathrm{C}^{16} \mathrm{O}+{ }^{12} \mathrm{C}^{18} \mathrm{O}$ mixture, further bands appear at 2020.7 and $1884.2 \mathrm{~cm}^{-1}$, which is appropriate for the presence of two carbonyl groups in this molecule. With the $\mathrm{D}_{2} \mathrm{O}$ isotope, the $\mathrm{C}-\mathrm{O}$ stretching absorptions shift very slightly (Table 1) and the 1577.4, 1543.8, and $1549.4 \mathrm{~cm}^{-1}$ absorptions shift to $1138.4,1120.4$, and $1116.9 \mathrm{~cm}^{-1}$. The band at $702.6 \mathrm{~cm}^{-1}$ in the Ti-OH region shifts to 657.2 and $656.36 \mathrm{~cm}^{-1}$ with the $\mathrm{H}_{2}{ }^{18} \mathrm{O}$ and $\mathrm{D}_{2} \mathrm{O}$ isotopes, respectively (Table 1 and figure S3).

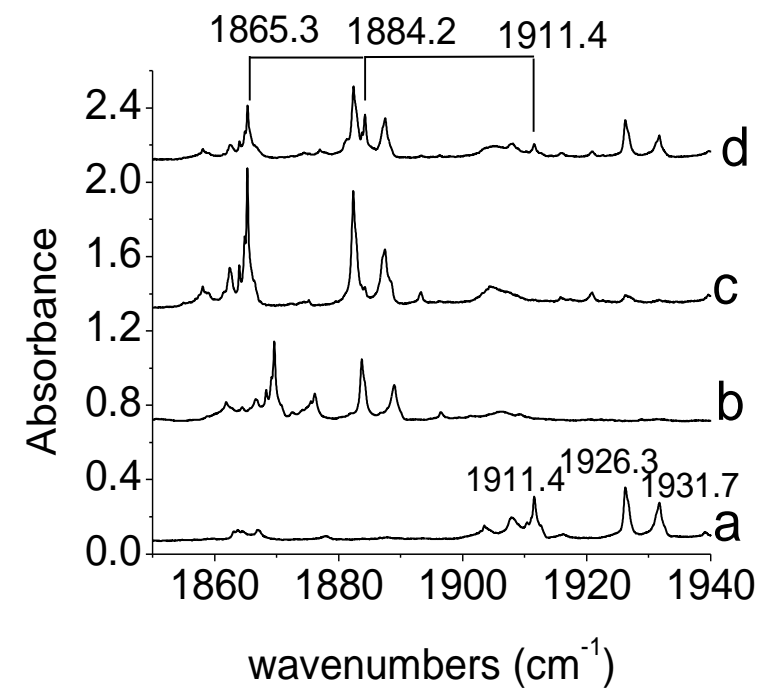

Figure 6. Infrared spectra in the $\mathrm{C}-\mathrm{O}$ stretching regions of the $\mathrm{Ti}+\mathrm{CO}+\mathrm{H}_{2} \mathrm{O}$ reaction products with $\mathrm{Ti} / \mathrm{CO} / \mathrm{H}_{2} \mathrm{O} / \mathrm{Ar}=0.3 / 20 / 10 / 100$ for the isotopes (a) $\mathrm{CO},(b){ }^{13} \mathrm{CO}$, (c) $\mathrm{C}^{18} \mathrm{O}$, and (d) $\mathrm{CO}+\mathrm{C}^{18} \mathrm{O}$.

Also, at this point, the experimental data alone have already given some general picture for the molecular shape for the two observed species. The two species have a Ti-H bond since we observed the bands at 1577.4 and $1549.4 \mathrm{~cm}^{-1}$, and one of these species has a Ti-OH bond since we observed a band at 
$702.6 \mathrm{~cm}^{-1}$. These absorptions are very close to the Ti-H and Ti-OH stretching vibrations observed at 1538.9 and $699.4 \mathrm{~cm}^{-1}$, respectively, in the HTiOH molecules ${ }^{14}$. Since we also observe bands in the C-O stretching region, the two species could be considered like a $\mathrm{HTiOH}$ molecule with one and two $\mathrm{CO}$ molecules coordinated to the Ti atom as a $\mathrm{HTiOH}-\mathrm{CO}$ and $\mathrm{HTiOH}-(\mathrm{CO})_{2}$ structure.

\section{THEORETICAL CALCULATIONS}

Quantum chemical calculations have been performed to determine the molecular structures and to support the vibrational frequency analysis of the observed molecules. Previous theoretical works by Zhou and co-workers, using B3LYP functionals, on the $\mathrm{Ti}+\mathrm{H}_{2} \mathrm{O}$ reaction showed that $\mathrm{HTiOH}$ has a ${ }^{3} \mathrm{~A}^{\prime \prime}$ ground state $^{14}$ and that two reaction paths are possible on the singlet surface. One path is the hydrogen atoms transfer from oxygen to the metal center to form $\mathrm{H}_{2} \mathrm{TiO}$ with ${ }^{1} \mathrm{~A}$ " ground state, and the other path leads to $\mathrm{H}_{2}$ elimination to form the TiO monoxide.

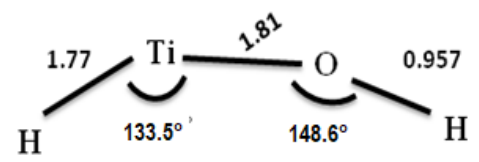

${ }^{3} \mathbf{A}^{\prime \prime}$

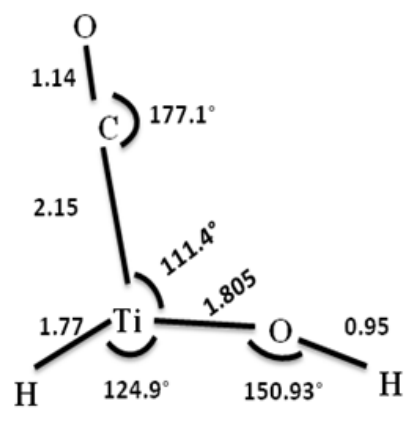

$$
\begin{gathered}
\text { Triplet state }{ }^{3} \mathrm{~A}^{\prime \prime} \\
\mathrm{D}_{0}(\mathrm{HTiOH}+\mathrm{CO})=-18.5 \mathrm{kcal} / \mathrm{mol}
\end{gathered}
$$

Figure 7. Optimized geometrical parameters (distance in $\AA$ and angles in degrees) and ZPE corrected binding energy (in kcal/mol) for the ground state of the HTiOH and HTiOH-CO molecules.

HTiOH-CO: The B3LYP calculations predict that HTiOH-CO is a stable molecule in the ${ }^{3} \mathrm{~A}^{\prime \prime}$ ground electronic state with a pseudo $\mathrm{D}_{3 \mathrm{~h}}$ symmetry planar structure (Figure 7). Binding energy corrected for the zero point energy has been calculated to be $-18.5 \mathrm{kcal} / \mathrm{mol}$ with respect to $\mathrm{E}(\mathrm{HTiOH})+\mathrm{E}(\mathrm{CO})$. The $\mathrm{H}-\mathrm{Ti}-\mathrm{O}$ angle is $124.9^{\circ}$, smaller than that in $\mathrm{HTiOH}$ by $9^{\circ}$. The $\mathrm{C}-\mathrm{O}$ and $\mathrm{Ti}-\mathrm{C}$ bond lengths are 1.14 and $2.15 \AA$ and the $\mathrm{Ti}-\mathrm{H}$, Ti-O, and $\mathrm{O}-\mathrm{H}$ bond lengths are almost equal in $\mathrm{HTiOH}-\mathrm{CO}$ and $\mathrm{HTiOH}$. The calculated 
vibrational frequencies corresponding to the observed bands are listed in Table 2. The C-O, Ti-H and Ti-OH stretching frequencies are calculated at 2063, 1574, and $761 \mathrm{~cm}^{-1}$, and the $\mathrm{H}-\mathrm{Ti}-\mathrm{O}$ out of plane bending mode is calculated at $317 \mathrm{~cm}^{-1}$.

HTiOH-(CO) $)_{2}$ : the DFT calculations show that $\mathrm{HTiOH}-(\mathrm{CO})_{2}$ molecule has singlet electronic state ${ }^{1} \mathrm{~A}$ with a pseudo $\mathrm{T}_{\mathrm{d}}$ symmetry (Figure 8). Binding energy corrected for the zero point energy has been calculated to be $-23.2 \mathrm{kcal} / \mathrm{mol}$ with respect $\mathrm{E}(\mathrm{HTiOH}-\mathrm{CO})+\mathrm{E}(\mathrm{CO})$. The two carbonyls groups are equivalent and the $\mathrm{C}$ O bond length slightly increases by $0.002 \AA$ compared to the HTiOH-CO. The Ti-C bond length shows a decrease of about $0.07 \AA$ (Ti-C=2.08 $\AA$ ). The O-H, C-O symmetric and antisymmetric, Ti-H and Ti-OH stretching frequencies are calculated at 3911, 2104, 2026, 1628, and $778 \mathrm{~cm}^{-1}$ (Table 3). For these two molecules a complete listing of all of the calculated frequencies is provided in the Supporting Information.

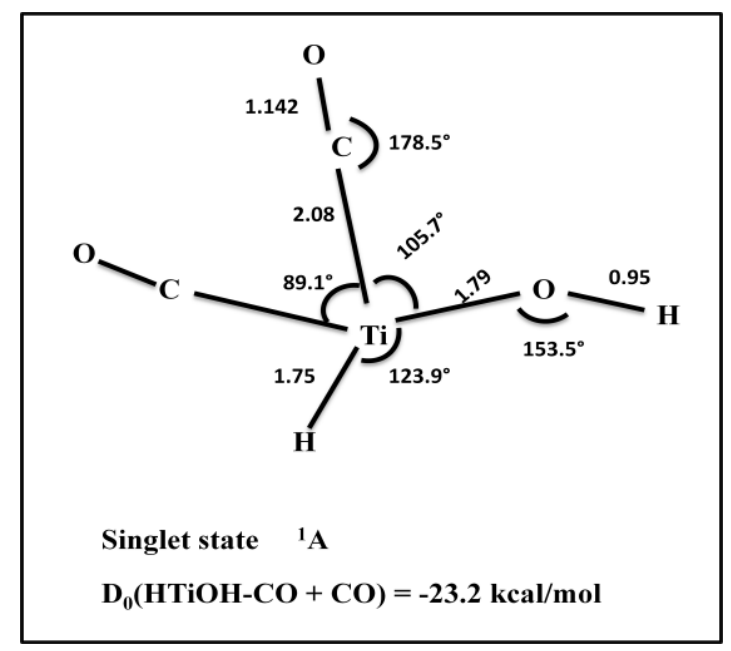

Figure 8. Optimized geometrical parameters (distance in $\AA$ and angles in degrees) and ZPE corrected binding energy (in kcal/mol) for the ground state of the HTiOH-(CO $)_{2}$ molecule.

\section{Bonding analysis}

The Laplacian isolines of the charge density enable us to identify regions where the charge density is concentrated (blue bullet in Figure 9). Consequently, we can easily find the most favorable direction for a 
nucleophilic attack. Such a direction is shown by arrows in Figure 9. Preferred direction for the interaction between $\mathrm{CO}$ and $\mathrm{HTiOH}$ leads to a planar structure (Figure 9-b). Note that between two electrophilic (indicated by arrows in Figure 9-b) regions located on the HTiOH-CO complex only one could accommodate an electron-rich region of another molecule. That is the addition of a second $\mathrm{CO}$ modifies the position of the first $\mathrm{CO}$ within the possible angle imposed by the two charge-concentration regions $\left(\approx 200^{\circ}\right)$ located on the $\mathrm{Ti}$ atom. As shown in Figure 9-c, the fact that the $\mathrm{Ti}$ atom is able to form a tetrahedral structure when its coordination sphere is completed with 4 ligands could be understood by the spatial organization of charge-concentration and charge-depletion regions. It is worth noting that all four valence electrons around Ti pair to give a tetra-coordinated species in the spin singlet state, when Ti center is tetraligated, while $\mathrm{HTiOH}-\mathrm{CO}$ has a triplet state with two unpaired $\alpha$ electrons delocalized on the $\mathrm{Ti}$ and $\mathrm{C}$ atoms.

(a)

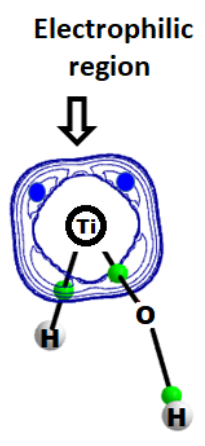

(b)

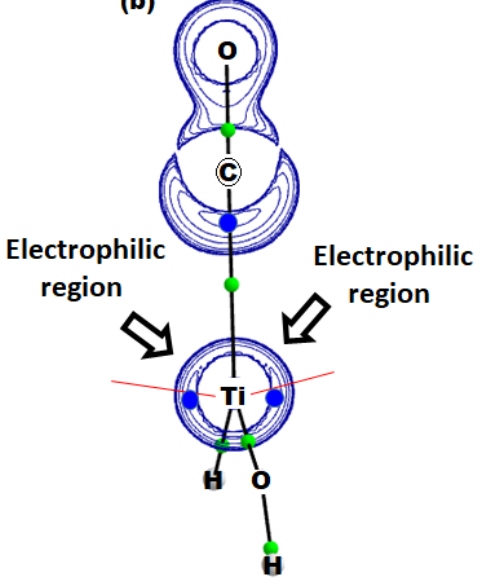

(c)

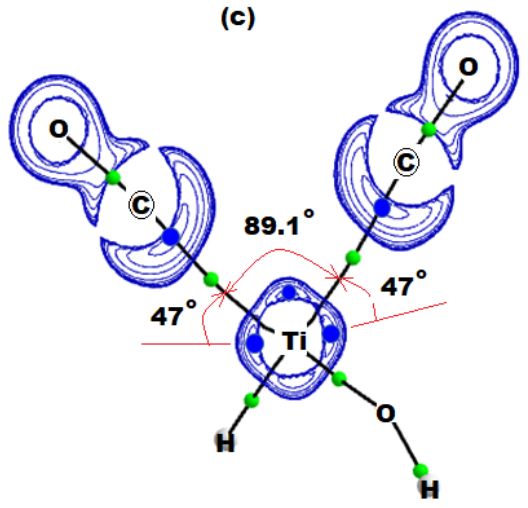

Figure 9. Isocurves of the Laplacian of the electronic density $\left(\nabla^{2} \rho<0\right.$, blue lines) for three compounds. Regions of charge concentration are indicated by blue bullet. The green bullet is the bond critical points. Electrophilic regions corresponding to the charge depletion are shown by arrows. Successive addition of CO molecule is also indicated.

Thanks to the presence of two $\sigma$-ligands $(\mathrm{H}$ and $\mathrm{OH})$, the formal oxidation state of $\mathrm{Ti}$ is +2 within both $\mathrm{HTiOH}-\mathrm{CO}$ and $\mathrm{HTiOH}-(\mathrm{CO})_{2}$. Thus, monomeric Ti(II), with two d-electrons, forms either a paramagnetic complex with two unpaired electrons when one carbonyl is added to $\mathrm{HTiOH}$, or a diamagnetic complex with $\alpha \beta$ paired electrons when two carbonyls are added to $\mathrm{HTiOH}$. For $\mathrm{HTiOH}-(\mathrm{CO})_{2}$, the $\mathrm{Ti}(\mathrm{II})$ center has a 
total 10 electrons (four electrons donated by two CO $\pi$-ligands) which is clearly less than 18 electrons ${ }^{27}$. Accordingly, the $\mathrm{HTiOH}-(\mathrm{CO})_{2}$ complex presents actually a coordinative unsaturation with respect to $16 / 18$ electron-rule so that it is able to accommodate additional CO. Nevertheless, we want to emphasize the fact that the singlet ground state is obtained for the experimentally observed $\mathrm{HTiOH}-(\mathrm{CO})_{2}$ which is thermally quite stable: the calculated Gibbs free energy of formation per carbonyl was found to be $\Delta \mathrm{G}(\mathrm{HTiOH}-$ $(\mathrm{CO}) 2)=-11.5 \mathrm{kcal} / \mathrm{mol}$.

It is well established that the charge density at bond critical point is a good descriptor to estimate the bond strength ${ }^{28,29}$. In going from $\mathrm{HTiOH}-\mathrm{CO}$ to $\mathrm{HTiOH}-(\mathrm{CO})_{2}$, the charge density at the $\mathrm{C}-\mathrm{O}$ bond critical point slightly decreases from 0.486 to $0.484 e$, while it increases for the $\mathrm{C}-\mathrm{Ti}$ bond critical point $(0.071$ vs. $0.086 e)$. These trends are consistent with the change in the binding energy $(-19.7 v s .-25.4 \mathrm{kcal} / \mathrm{mol})$, the $\mathrm{C}-$ O bond length (1.140 vs. $1.142 \AA$ ), and the $\mathrm{C}-\mathrm{Ti}$ bond distance $(2.15$ vs. $2.08 \AA)$ resulted from the successive addition of $\mathrm{CO}$ to $\mathrm{HTiOH}$.

\section{Vibrational analysis and comparison with calculations.}

All the experimentally observed vibrational frequencies for various isotopic substitutions as well as corresponding DFT - calculated harmonic wavenumbers, and the relative infrared intensities are listed in Table 2 and 3. The calculated frequency shifts due to the isotopic ${ }^{12} \mathrm{C}^{16} \mathrm{O} /{ }^{13} \mathrm{C}^{16} \mathrm{O},{ }^{12} \mathrm{C}^{16} \mathrm{O} /{ }^{12} \mathrm{C}^{18} \mathrm{O}, \mathrm{H}_{2} \mathrm{O} / \mathrm{H}_{2}{ }^{18} \mathrm{O}$ and $\mathrm{H}_{2} \mathrm{O} / \mathrm{D}_{2}{ }^{18} \mathrm{O}$ substitutions agree well with the experimental values for the two observed molecules. The observation of very weak shifts with isotopic labeled ${ }^{13} \mathrm{C}^{16} \mathrm{O}+\mathrm{H}_{2}{ }^{16} \mathrm{O}$ and ${ }^{12} \mathrm{C}^{16} \mathrm{O}+\mathrm{H}_{2}{ }^{18} \mathrm{O}$ and of large shifts with ${ }^{12} \mathrm{C}^{16} \mathrm{O}+\mathrm{D}_{2}{ }^{18} \mathrm{O}$ confirms the assignments for the Ti-H and Ti-OH stretching modes. On the basis of concentration and annealing effects, we can attribute the band in far infrared at $330.4 \mathrm{~cm}^{-1}$ to $\mathrm{HTiOH}-\mathrm{CO}$. We have two calculated bands at 317 and $318 \mathrm{~cm}^{-1}$ corresponding to $\gamma_{\mathrm{HOTiH}}$ and $\delta_{\mathrm{TiOH}}$ bending modes but the calculated $\mathrm{H}_{2} \mathrm{O} / \mathrm{D}_{2}{ }^{18} \mathrm{O}$ frequency shifts are 52 and $29 \mathrm{~cm}^{-1}$, respectively. Since the experimental value is 54.9 $\mathrm{cm}^{-1}$, we can attribute the band at $330.4 \mathrm{~cm}^{-1}$ to the $\gamma_{\mathrm{HOTiH}}$ bending mode. Accounting for the detectivity of the argon matrix setup, only modes with intensities larger than $35 \mathrm{~km} / \mathrm{mol}$ are likely to be observed. For 
$\mathrm{HTiOH}-\mathrm{CO}$, in addition to the bands in Table 2, six other vibrational frequencies have been calculated to have an IR intensity greater than $35 \mathrm{Km} / \mathrm{mol}$ at $255,284,318,345,418$, and $3914 \mathrm{~cm}^{-1}$, but the corresponding spectral regions are congested by strong absorptions of water and $\mathrm{Ti}+\mathrm{H}_{2} \mathrm{O}$ reaction products.

Table 2. Comparison between experimental frequencies and calculated harmonic data (in $\mathrm{cm}^{-1}$ ) of the observed HTiOH-CO molecule with the isotopic Shifts.

\begin{tabular}{ccccccccccc}
\hline \multicolumn{7}{c}{ Experimental } & \multicolumn{1}{c}{ DFT } \\
\hline${ }^{12} \mathrm{C}^{16} \mathrm{O}$ & ${ }^{13} \mathrm{C}^{16} \mathrm{O}$ & ${ }^{12} \mathrm{C}^{18} \mathrm{O}$ & $\mathrm{H}_{2}{ }^{18} \mathrm{O}$ & $\mathrm{D}_{2}{ }^{18} \mathrm{O}$ & ${ }^{12} \mathrm{C}^{16} \mathrm{O}$ & ${ }^{13} \mathrm{C}^{16} \mathrm{O}$ & ${ }^{12} \mathrm{C}^{18} \mathrm{O}$ & $\mathrm{H}_{2}{ }^{18} \mathrm{O}$ & $\mathrm{D}_{2}{ }^{18} \mathrm{O}$ & Modes \\
\hline $1926.3(100)^{\mathrm{a}}$ & 42.6 & 44.0 & 0.2 & 2.8 & $2063(100)^{\mathrm{a}}$ & 47 & 49 & 0 & 1 & $v_{\mathrm{CO}}$ \\
$1543.8(34)$ & 0.4 & 0.5 & 0.2 & 426.9 & $1574(51)$ & 0 & 0 & 0 & 448 & $v_{\text {Ti-H }}$ \\
$702.6(15)$ & - & 0.6 & 27.7 & 45.7 & $761(23)$ & 0 & 0 & 27 & 46 & $v_{\text {Ti-OH }}$ \\
$330.4(17)$ & 2.9 & 0.8 & 1.4 & 54.9 & $317(16)$ & 4 & 2 & 2 & 52 & $\gamma_{\text {HOTiH }}$ \\
\hline
\end{tabular}

${ }^{a}$ relative infrared intensities in parenthesis normalized with respect to the CO mode.

Absorption bands observed at 1931.7 and $1926.3 \mathrm{~cm}^{-1}$ are assigned to two sites of CO stretching mode of HTiOH-CO, and the two absorptions at 2039.9 and $1911.4 \mathrm{~cm}^{-1}$ have been assigned to symmetric and antisymmetric $\mathrm{CO}$ stretching modes of $\mathrm{HTiOH}-(\mathrm{CO})_{2}$. Furthermore the calculated frequency shifts due to the ${ }^{12} \mathrm{C}^{16} \mathrm{O} /{ }^{13} \mathrm{C}^{16} \mathrm{O}$ and ${ }^{12} \mathrm{C}^{16} \mathrm{O} /{ }^{12} \mathrm{C}^{18} \mathrm{O}$ isotopic substitutions agree well with experimental values and give strong support for the assignment of these bands. Finally, the O-H stretching mode of HTiOH-CO is not observed but that of HTiOH- $(\mathrm{CO})_{2}$ is observed at $3745.5 \mathrm{~cm}^{-1}$.

Table 3. Comparison between experimental frequencies and calculated harmonic data (in $\mathrm{cm}^{-1}$ ) of the observed HTiOH-(CO $)_{2}$ molecule with the isotopic Shifts.

\begin{tabular}{ccccccccccc}
\hline \multicolumn{1}{c}{ Experimental } & \multicolumn{1}{c}{ DFT } \\
\hline${ }^{12} \mathrm{C}^{16} \mathrm{O}$ & ${ }^{13} \mathrm{C}^{16} \mathrm{O}$ & ${ }^{12} \mathrm{C}^{18} \mathrm{O}$ & $\mathrm{H}_{2}{ }^{18} \mathrm{O}$ & $\mathrm{D}_{2}{ }^{18} \mathrm{O}$ & ${ }^{12} \mathrm{C}^{16} \mathrm{O}$ & ${ }^{13} \mathrm{C}^{16} \mathrm{O}$ & ${ }^{12} \mathrm{C}^{18} \mathrm{O}$ & $\mathrm{H}_{2}{ }^{18} \mathrm{O}$ & $\mathrm{D}_{2}{ }^{18} \mathrm{O}$ & Modes \\
\hline $3745.5(12)^{\mathrm{a}}$ & 0.1 & 0 & 12.0 & - & $3911(19)^{\mathrm{a}}$ & 0 & 0 & 13 & 1079 & $v_{\mathrm{OH}}$
\end{tabular}




$\begin{array}{ccccccccccc}2039.9(13) & 45.9 & 46.4 & 0.1 & 1.0 & 2104(30) & 48 & 49 & 0 & 1 & v_{\mathrm{CO}} \mathrm{sym} \\ 1911.4(100) & 41.8 & 46.1 & 0 & 0.6 & 2026(100) & 45 & 48 & 0 & 0 & v_{\mathrm{CO}} \text { asym } \\ 1577.4(17) & 0.1 & 0.1 & 0 & 439.0 & 1628(38) & 0 & 0 & 0 & 463 & v_{\mathrm{TiH}}\end{array}$

${ }^{a}$ relative infrared intensities in parenthesis normalized with respect to the $\mathrm{CO}$ mode.

Under the present experimental conditions, Ti atoms react with $\mathrm{H}_{2} \mathrm{O}$ and $\mathrm{CO}$ mixtures in solid argon. Since our thermal evaporation experiments indicate that the ground state titanium atoms do not react with $\mathrm{CO}$ spontaneously to form TiCO molecule, the first step of the reaction must start by the reaction between $\mathrm{Ti}$ and water, and we know that this reaction produces $\mathrm{HTiOH}$ spontaneously. The HTiOH molecule is produced mainly from reaction (1) during deposition:

(1) $\mathrm{Ti}\left({ }^{3} \mathrm{~F}\right)+\mathrm{H}_{2} \mathrm{O} \rightarrow \mathrm{HTiOH}\left({ }^{3} \mathrm{~A}^{\prime \prime}\right) \Delta \mathrm{E}=-63.5 \mathrm{kcal} / \mathrm{mol}$

The $\mathrm{HTiOH}-\mathrm{CO}$ molecule was formed by reaction (2). Our experimental observations suggest that the $\mathrm{HTiOH}-\mathrm{CO}$ is formed by reaction of $\mathrm{HTiOH}$ and $\mathrm{CO}$ whereas $\mathrm{HTiOH}-(\mathrm{CO})_{2}$ species is formed via $\mathrm{CO}$ addition (reaction (3)).

(2) $\mathrm{HTiOH}\left({ }^{3} \mathrm{~A}^{\prime \prime}\right)+\mathrm{CO}\left({ }^{1} \Sigma\right) \rightarrow \mathrm{HTiOH}-\mathrm{CO}\left({ }^{3} \mathrm{~A}^{\prime \prime}\right) \Delta \mathrm{E}=-19.7 \mathrm{kcal} / \mathrm{mol}$

(3) $\mathrm{HTiOH}-\mathrm{CO}\left({ }^{3} \mathrm{~A}^{\prime \prime}\right)+\mathrm{CO}\left({ }^{1} \Sigma\right) \rightarrow \mathrm{HTiOH}-(\mathrm{CO})_{2}\left({ }^{1} \mathrm{~A}\right) \Delta \mathrm{E}=-25.4 \mathrm{kcal} / \mathrm{mol}$

Owing to the cooperativity effect, addition of a second carbonyl is more stabilizing by $5.7 \mathrm{kcal} / \mathrm{mol}$ than that of the first CO ligand.

\section{CONCLUSION}

The reactions of thermal evaporated titanium atoms with water and carbon monoxide have been investigated using argon matrix isolation infrared absorption spectroscopy and density functional calculations. Results show that the inserted $\mathrm{HTiOH}$ molecule spontaneously reacts with $\mathrm{CO}$ to form the $\mathrm{HTiOH}-\mathrm{CO}$ molecule with planar structure in the ground triplet electronic state. The mono-ligated adduct reacts in turn with a second $\mathrm{CO}$ molecule to form $\mathrm{HTiOH}-(\mathrm{CO})_{2}$. The experimental data, with the help of 
isotopic effects, are fully supported by theoretical calculations. Bonding analysis within the QTAIM topology allowed us to rationalize the pseudo tetrahedral structure of the di-ligated $\mathrm{HTiOH}-(\mathrm{CO})_{2}$ compound. Particularly, we showed that the perfect spin pairing takes place when the coordination sphere of Ti(II) center is complemented by four ligands.

\section{Supporting information}

Infrared spectra in the $\mathrm{Ti}-\mathrm{H}$ and $\mathrm{O}-\mathrm{H}$ stretching regions with two different $\mathrm{CO} / \mathrm{Ar}$ molar ratios (Figure $\mathrm{S} 1$ ); Infrared spectra in the (a) after deposition at $12 \mathrm{~K}$ and (b) after annealing to $32 \mathrm{~K}$ (Figure S2); Isotopic study in the Ti-OH region for the isotopes (a) $\mathrm{CO} / \mathrm{H}_{2} \mathrm{O}$, (b) $\mathrm{CO} / \mathrm{H}_{2}{ }^{18} \mathrm{O}$, and (c) $\mathrm{CO} / \mathrm{H}_{2}{ }^{18} \mathrm{O}$ after annealing to $25 \mathrm{~K}$ (Figure S3); Calculated harmonic frequencies $\left(\mathrm{cm}^{-1}\right)$ and intensities $(\mathrm{km} / \mathrm{mol})$ for the HTiOH, HTiOH-CO, and $\mathrm{HTiOH}-(\mathrm{CO})_{2}$ molecules (Table S1).

TOC Graphic

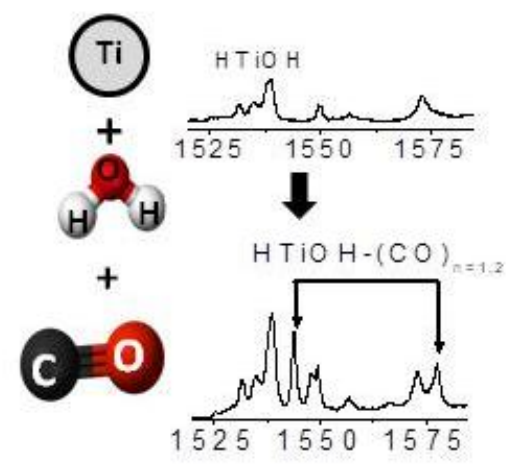

References

1. Navarro, R. M.; Pena, M. A.; Fierro, J. L. G. Hydrogen Production Reactions from Carbon Feedstocks: Fossil Fuels and Biomass. Chem. Rev. 2007, 107, 3952-3991.

2. Hilaire, S.; Wang, X.; Luo, T.; Gorte, R. J.;Wagner, J. A comparative study of water-gas-shift reaction over ceria supported metallic catalysts. Appl.Catal. A 2001, 215, 271-278. 
3. Chen, Y.Y.; Dong, M.; Wang, J. G.; Hayjun, J. On the Role of a Cobalt Promoter in a Water-GasShift Reaction on Co-MoS 2 . J. Phys. Chem. C 2010, 114, 16669-16676.

4. Panagiotopoulou, P.; Kondarides, D. I. Effect of morphological characteristics of $\mathrm{TiO}_{2}$-supported noble metal catalysts on their activity for the water-gas shift reaction. J. Catal. 2004, 225, 327-336.

5. Wang, Y. Y.; Zhang, D. J.; Zhu, R. X.; Zhang, C. Q. ; Liu, C. B. A Density Functional Theory Study of the Water-Gas Shift Reaction Promoted by Neutral, Anionic, and Cationic Gold Dimers. J. Phys. Chem. C 2009, 113, 6215-6220.

6. Wang, X.; Andrews, L. Reactions of Laser-Ablated Ruthenium Atoms with $\mathrm{CO}$ and $\mathrm{H}_{2}$ Mixtures: Infrared Spectra and Density Functional Theory Calculations of $\mathrm{H}_{2} \mathrm{Ru}(\mathrm{CO})_{\mathrm{x}}(\mathrm{x}=2-4)$ and $\left(\mathrm{H}_{2}\right) \mathrm{RuCO}$. J. Phy. Chem. A 2000, 104, 9892-9900,

7. Wang X.; Andrews, L. Infrared Spectra of $\mathrm{M}(\mathrm{OH})_{1,2,3}(\mathrm{M}=\mathrm{Mn}, \mathrm{Fe}, \mathrm{Co}, \mathrm{Ni})$ Molecules in Solid Argon and the Character of First Row Transition Metal Hydroxide Bonding. J. Phy. Chem. A 2006, 110, 10035-10045.

8. Lu, Z.H.; Jiang, L.; Xu, Q. Infrared Spectra and Density Functional Theory Calculations of the Tantalum and Niobium Carbonyl Dinitrogen Complexes. J. Chem. Phys. 2009, 131, 034512.

9. Lu, Z. H.; Xu, Q. CO-Promoted $\mathrm{N}_{2}$ Adsorption on Copper Atoms. Phys. Chem. Chem. Phys. 2010, 26, 7077-7082.

10. Xu, Q.; Jiang. L. Oxidation of Carbon Monoxide on Group 11 Metal Atoms: Matrix-Isolation Infrared Spectroscopic and Density Functional Theory Study. J. Phy. Chem. A 2006, 110, 26552662.

11. Gong, Y.; Zhou, M. Water Adsorption on Platinum Dioxide and Dioxygen Complex: Matrix Isolation Infrared Spectroscopic and Theoretical Study of Three $\mathrm{PtO}_{2}-\mathrm{H}_{2} \mathrm{O}$ Complexes. Chem. Phys. Chem. 2010, 11, 1888-1894.

12. Jian, J.; Zhang, Q.; Wu, X.; Zhou. M. Isocyanate Formation from Reactions of Early Lanthanide Metal Atoms with NO and CO in Solid Argon. J. Phys. Chem. A 2017, 121, 7861-7868.

13. Kauffman, J. L.; Hauge, R. H.; Margrave, J. L. Reactions of Atomic Scandium, Titanium, and Vanadium with Molecular Water at 15 K. J. Phys. Chem. 1985, 89, 3547-3551. 
14. Zhou, M.; Zhang, L.; Dong, J.; Qin, Q. Reactions of Group IV Metal Atoms with Water Molecules. Matrix Isolation FTIR and Theoretical Studies. J. Am. Chem. Soc. 2000, 122, 10680-10688.

15. Zhou, M.; Dong, J.; Zhang, L.; Qin, Q. Reactions of Group V Metal Atoms with Water Molecules. Matrix Isolation FTIR and Quantum Chemical Studies. J. Am. Chem. Soc. 2001, 123, 135-141.

16. Chertihin, G. V.; Andrews, L. Infrared Spectra of the Reaction Products of Laser-Ablated Titanium Atoms and Oxides with Carbon Monoxide in Solid Argon. J. Am. Chem. Soc. 1995, 117, 1595-1602.

17. Xu, Q.; Jiang, L.; Tsumori, N. Cyclo- $\mathrm{Ti}_{3}\left[\eta^{2}\left(\mu_{2^{-}} \mathrm{C}, \mathrm{O}\right)\right]_{3}$ : A Side- on- Bonded Polycarbonyl Titanium Cluster with Potentially Antiaromatic Character. Angew. Chem. Int. Ed. 2005, 44, 43384342.

18. Zhou, M.; Andrews, L. Infrared Spectra and Density Functional Calculations of Small Vanadium and Titanium Carbonyl Molecules and Anions in Solid Neon, J. Phys. Chem. A 1999, 103, 52595268.

19. Souvi, S. M.; Berkaine, N.; Alikhani, M. E.; Manceron, L. Neon-matrix spectroscopic and theoretical studies of the reactivity of titanium dimer with diatomic ligands: comparison of reactions with nitrogen and carbon monoxide. Phys. Chem. Chem. Phys. 2009, 11, 9831-9839.

20. Danset, D.; Manceron, L. Mid- and near-IR electronic absorption spectrum of CoO isolated in solid neon. Vibronic data for low-lying electronic states. J. Phys. Chem. A 2003,107, 11324-11330.

21. Feller, D. The Role of Databases in Support of Computational Chemistry Calculations. J. Comp. Chem. 1996, 17, 1571-1586.

22. Schuchardt, K. L.; Didier, B.T.; Elsethagen, T.; Sun, L.; Gurumoorthi, V.; Chase, J.; Li, J.; Windus, T.L. Basis Set Exchange: A Community Database for Computational Sciences. J. Chem. Inf. Model. 2007, 47, 1045-1052.

23. Frisch, M. J.; Trucks, G. W.; Schlegel, H. B. et al. Gaussian 09, Revision D.01, Gaussian Inc.: Wallingford CT, 2009.

24. Bader, R. F. W. Atomes in Molecules: A Quantum Theory, 1994, Oxford: Clarendon Press.

25. AIMAll (Version 19.10.12), Todd A. Keith, TK Gristmill Software, Overland Park KS, USA, 2019 (aim.tkgristmill.com). 
26. Abe, H.; Yamada, K. M. T. Spectroscopic Identification of the CO- $\mathrm{H}_{2} \mathrm{O}$ 2-1 Cluster Trapped in an Argon Matrix. J. Chem. Phys. 2004, 121, 7803-7812.

27. Hill, A.F. Organotransition Metal Chemistry; Abel, E. W., Ed.; Royal Society of Chemistry: Cambridge, UK, 2002.

28. Alikhani, E.; Fuster, F.; Madebene, B.; Grabowski, S. J. Topological Reaction Sites - Very Strong Chalcogen Bonds. Phys. Chem. Chem. Phys. 2014, 16, 2430-2442.

29. Grabowski, S. J. QTAIM Characteristics of Halogen Bond and Related Interactions. J. Phys. Chem. A 2012, 116, 1838-1845. 